\title{
Application of the Ccme-Wqi Model in Assessing the Water Quality of the Aboabo River, Kumasi-Ghana
}

\author{
Charles Gyamfi ${ }^{1,2}$, Robert Boakye ${ }^{1}$, Esi Awuah ${ }^{1}$, \& Frederick Anyemedu ${ }^{1}$ \\ ${ }^{1}$ Department of Civil Engineering, Kwame Nkrumah University of Science and Technology, Kumasi, Ghana \\ ${ }^{2}$ School of Agriculture and Bio-Resources Engineering, Anglican University College of Technology, Nkoranza, \\ Ghana \\ Correspondence: Charles Gyamfi, Department of Civil Engineering, Kwame Nkrumah University of Science and \\ Technology, Kumasi, Ghana. Tel: 233-243-212-413. E-mail: gyamficharles84@yahoo.com
}

Received: August 10, 2013 Accepted: September 5, 2013 Online Published: September 11, 2013

doi:10.5539/jsd.v6n10p1 URL: http://dx.doi.org/10.5539/jsd.v6n10p1

\begin{abstract}
This paper examines the water quality of the Aboabo River in Kumasi, Ghana using the Canadian Council of Ministers of the Environment water quality index (CCME-WQI).Water samples were collected from five sampling stations namely; Pankrono, Moshie Zongo, Aboabo, Asokwa and Atonsu. The model employs both bacteriological and physicochemical parameters namely Escherichia coli (E-Coli), pH, Temperature, Total dissolve solids, Total phosphate, Nitrate, Biological oxygen demand (BOD) and Dissolved oxygen (DO) in the determination of the water quality index of the Aboabo River. Findings of the model classify the Aboabo River as poor with overall water quality index of 17.05. Station indices developed using the model were 19.87, 19.60, 15.67, 14.40, 15.73 for Pankrono, Moshie Zongo, Aboabo, Asokwa and Atonsu respectively. The index at each station classifies the River as poor. The deteriorating nature of the Aboabo River is directly linked to poor sanitary conditions prevalent in the Aboabo Catchment as well as the presence of cottage industries that discharge their effluent into the river.
\end{abstract}

Keywords: water quality, model, water quality index, Aboabo River, catchment

\section{Introduction}

The ravaging trends at which surface water resources are deteriorating have been a matter of concern for the international community (United Nations Environment Programme [UNEP], 1997). At the centre of this phenomenon are anthropogenic activities which are the major causatives of pollution of surface water resources (Danquah, Abass, \& Nikoi, 2011). As acknowledged by Chimnoy and Raziuddin (2002), the influence of waste water on the quality of water bodies cannot be overlooked. The effect due to the pollution of these vital resources is seen in the destruction of various species of aquatic flora and fauna (Devi \& Kothathi, 2012). In addition to this, is the fact that these resources are rendered unwholesome for drinking (UNEP, 2006) and even for other beneficial purposes such agriculture and industrial use.

Water quality therefore becomes a useful tool in ascertaining the extent of pollution or otherwise of a water body and hence the implementation of the appropriate measures to curb the issue of pollution of water sources. The quality of water is determined by comparing physical, chemical and bacteriological parameters of water samples with established water quality guidelines. The guidelines are established based on scientifically acceptable levels of toxicity to either human health or aquatic life (Al-Janabi, 2012).

In this study, the Canadian council of ministers of the environment (CCME-WQI) model has been used in the assessment of the pollution level of the Aboabo stream. The study sought to use this model due to its simplicity but robust nature of reporting water quality issues (UNEP, 2007; CCME, 2001). It provides a simplistic way of interpreting water quality parameters and hence its influence on policy makers and the general public. It is however not a substitute for detailed analysis of data (Khan, Paterson, \& Khan, 2004). Essentially, the model uses three elements namely; Scope - the number of water quality parameters (variables) not meeting water quality objectives (F1); Frequency - the number of times the objectives are not met (F2) and Amplitude - the extent to which the objectives are not met (F3). These are fixed in mathematical expressions to arrive at water quality indices used in determining the quality of the water body. The study assesses the water quality of the 
Aboabo River for drinking water purposes based on the drinking water objectives set by the World Health Organization (WHO).

\section{Study Area}

Kumasi Metropolitan Assembly (KMA) where the study river is located is found within the Ashanti region of Ghana. It covers a total land area of $254 \mathrm{~km}^{2}$, stretching between latitude $6.35^{\circ}-6.40^{\circ} \mathrm{N}$ and longitude $1.30^{\circ}$ $1.35^{\circ} \mathrm{W}$ with elevation between 250 - 300 meters above sea level. The climate of the region is that of wet sub equatorial climate with average minimum and maximum temperatures of $21.5^{\circ} \mathrm{C}$ and $30.7^{\circ} \mathrm{C}$ respectively. The Kumasi metropolis experiences a double maxima rainfall regime (214.3 mm in June and 165.2mm in September) The first rainy season is from mid-March to early July whilst the second starts from late August to early October. The dry season is experienced from November to early March (Suraj, 2004). The Aboabo River originates from Pankrono running through Buokrom, Moshie Zongo, Aboabo, Anloga, Asokwa and Atonsu. The Aboabo catchment is occupied by several cottage industries.

\section{Materials and Methods}

\subsection{Water Sampling and Laboratory Analysis}

The sampling period lasted for six months spanning January-June, 2013. A weekly sampling frequency was employed in this study. Bearing in mind the short period of the research, field data was augmented with existing secondary data. Samples of water were collected from the River at five different stations. The stations were selected to include one location at the upstream (Pankrono), three at the midstream (Moshie Zongo, Aboabo and Asokwa) and one downstream (Atonsu) (Figure 1). Selection of the stations was informed by the existence of small scale industries which has the potential of impacting water quality of the river. These stations are also known to be highly populated with poor environmental sanitary conditions. With the help of hand held GPS etrex VISTA HCX, the sampling locations were geo-referenced to ensure consistency in subsequent sampling. Water samples collected were stored in pre-rinsed 1.5 litres voltic bottle. Subsequently, the samples were transported to the Kwame Nkrumah University of Science and Technology (KNUST) Civil Engineering laboratory for analysis. The water samples were tested for $\mathrm{pH}$, Temperature, Total dissolve solids (TDS), Biological oxygen demand (BOD), Dissolved oxygen (DO), Turbidity, Total phosphorus and Escherichia Coli (E-coli). In-situ measurements were carried out on $\mathrm{pH}$ and temperature using $\mathrm{PC} 300$ waterproof EC/TDS/pH/Temperature meter.

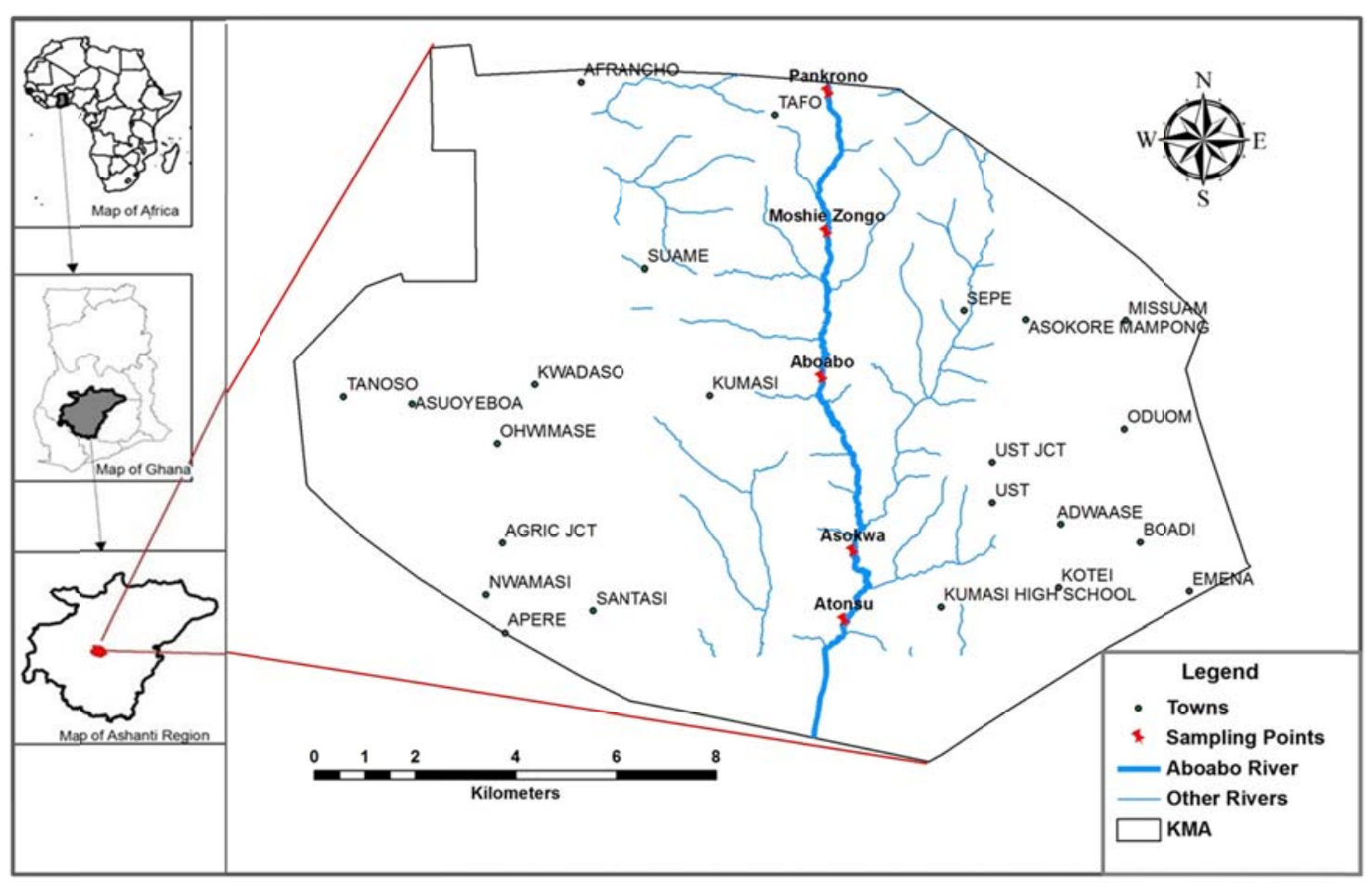

Figure 1. Sampling points locations 


\subsection{Conceptual Framework of CCME-WQI Model}

The water quality index (WQI) developed by the Canadian council of ministers of the environment (CCME) employs the combination of three essential measures of variance (Scope, Frequency and Amplitude). The combination of these measures of variance produces a set of range of values (Table 1) classifying quality of water into five classes namely; poor, marginal, fair, good and excellent.

Table 1. CCME-WQI categorization schema

\begin{tabular}{cc}
\hline Rank & WQI Value \\
\hline Excellent & $95-100$ \\
Good & $80-94$ \\
Fair & $65-79$ \\
Marginal & $45-64$ \\
Poor & $0-44$ \\
\hline
\end{tabular}

The detailed formulation of the WQI as described in the Canadian WQI Technical report is as follows:

Scope $\left(F_{1}\right)$ represents the extent of water quality guideline non-compliance over the time period of interest. Mathematically, $\mathrm{F}_{1}$ is expressed as indicated in Equation 1.

$$
F_{1}=[(\text { Number of failed variables }) /(\text { Total Number of Variables })] * 100
$$

The measure of frequency $\left(\mathrm{F}_{2}\right)$ represents the percentage of individual tests that do not meet objectives (failed tests). Shown in Equation 2 is the estimation formula.

$$
F_{2}=[(\text { Number of failed Tests }) /(\text { Total Number of Tests })] * 100
$$

The measure of Amplitude $\left(\mathrm{F}_{3}\right)$ represents the amount by which failed tests do not meet their objectives and is calculated in three steps as follows;

Step 1: Calculation of Excursion

Excursion is the number of times an individual concentration is

(1) Greater than the objective when the objective under consideration is maximum. In this case the excursion is calculated as

$$
\text { Excursion }=[\text { Failed Test Value i/Objective }]-1
$$

(2) Less than the objective when the objective under consideration is minimum. The expression for the excursion in this case is given in Equation 4

$$
\text { Excursion }=[\text { Objective } / \text { Failed Test Value } i]-1
$$

Step 2: Estimation of Normalised Sum of Excursions

The normalized sum of excursions (nse), represents the collective amount by which individual tests are out of compliance. It is estimated by summing the excursions of individual tests from their objectives and dividing by the total number of tests for both those meeting objectives and those not meeting objectives (Equation 5)

Step 3: Estimation of $\mathrm{F}_{3}$ (Amplitude)

$$
\text { nse }=\frac{\sum_{i=1}^{n} \text { Excursion }}{\text { Number of Tests }}
$$

$\mathrm{F}_{3}$ (Amplitude) is calculated by an asymptotic function that scales the normalized sum of the excursions from objectives to yield a range of values from 0 to 100 .

$$
F_{3}=[n s e /(0.01 n s e+0.01)]
$$

Finally, the CCME-WQI is calculated using Equation 7

$$
W Q I=100-\left[\frac{\sqrt{F_{1}^{2}+F_{2}^{2}+F_{3}^{2}}}{1.732}\right]
$$


The drinking water objectives established by WHO (Table 2) formed the basis with which samples from the study river were compared.

Table 2. Water quality objectives used in the model

\begin{tabular}{lc}
\hline \multicolumn{1}{c}{ Water Quality Parameter } & WHO Guideline Value \\
\hline $\mathrm{pH}$ & $6.5-8.5$ \\
Temperature $\left({ }^{\circ} \mathrm{C}\right)$ & 25 \\
Nitrate $(\mathrm{mg} / \mathrm{l})$ & 5 \\
Total Dissolved Solids, TDS (mg/l) & 1000 \\
Total phosphorus (mg/l) & 0.03 \\
Biological Oxygen Demand, BOD (mg/l) & 4 \\
Dissolved Oxygen, DO (mg/l) & $5-9.5$ \\
Escherichia Coli, E-coli (Counts/100ml) & 0 \\
Turbidity (NTU) & 5 \\
\hline
\end{tabular}

Adopted from WHO (2011).

\section{Results and Discussions}

The water quality indices have been developed to reflect the Physico-chemical and Bacteriological quality of surface water resources in this case the Aboabo River. Findings from the model are an indication of the deteriorating nature of the river along all the stations of the river where readings were taken (Figure 2). At Pankrono, the model predicted an index of 19.87. Comparing this to the categories of WQI developed by CCME (2001), the river is classified to have poor quality. At the midstream stations, namely; Moshie Zongo, Aboabo and Asokwa the model gave indices of 19.60, 15.67 and 14.40 respectively and hence the water quality at these stations are said to be of poor quality. It could thus be said that as the River water flows downstream the quality of water deteriorates. This is mainly due to the enormous activities along this stretch of the river. At the downstream, Atonsu the model recorded an index of 15.73 which represents an increase of $8.46 \%$ over the index recorded at Asokwa. The increase could probably be due to the dilution effect of the sisa stream a tributary of the Aboabo River which has its confluence in Asokwa. The overall index for the Aboabo River considering all sampling stations is 17.05

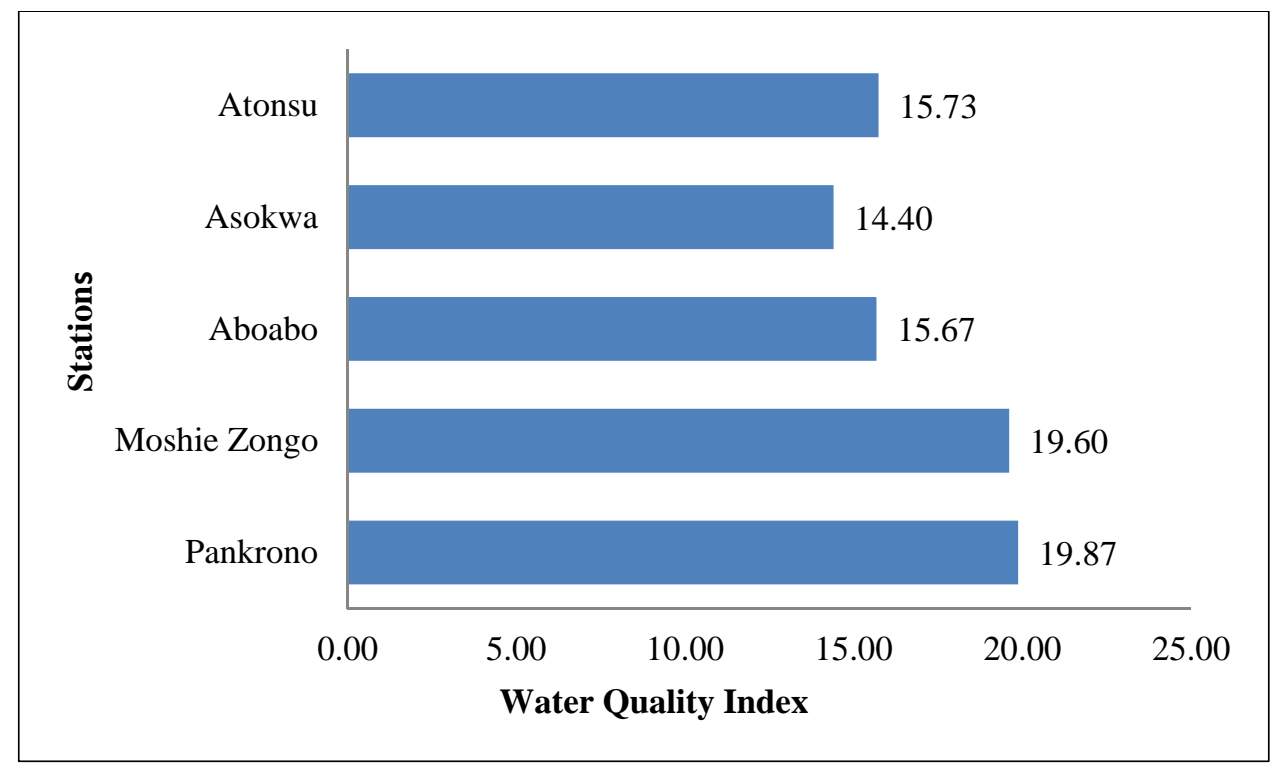

Figure 2. Water quality index of Aboabo River 
The result of pH varied between 6.5 and 7.8 (Table 3) with the maximum pH of 7.8 occurring at Aboabo. The recorded ranges of $\mathrm{pH}$ for this study were found to be within the range of 6.5-8.5 stipulated for drinking and domestic purposes (WHO,1993) and also agreed with that recommended for fresh water resources (United States Environmental Protection Agency [USEPA], 2001; UNEP, 2008). It has however been acknowledged, that pH values departing increasingly from the normally found levels will have a significant effect on fish, leading ultimately to mortality (USEPA, 2001).

Turbidity values ranged from 1.3 to 377 NTU (Table 3). The background levels for turbidity ranges from 0 to 5 NTU (Water Resources Commission [WRC], 2003). However, results obtained clearly exceed the background levels stipulated by WRC and this could possibly be due to urban runoff and industrial effluents (USEPA, 1997) from the Aboabo Catchment. The effect of the high turbidity is the shielding of organisms' hence making water treatment inefficient (WHO, 2011). Variations in turbidity in all the five sampling stations were statistically insignificant $(\mathrm{p}>0.05)$.

Temperatures ranged between $25.8{ }^{\circ} \mathrm{C}$ and $36.2{ }^{\circ} \mathrm{C}$ (Table 3). According to Brungs and Jones (1977), the permissible temperature range for sustaining aquatic life from microbes to fish is $5{ }^{\circ} \mathrm{C}-35^{\circ} \mathrm{C}$. A correlation analysis revealed that about $65 \%$ of the variability in temperature can be explained by turbidity.

Meanwhile, observed values of Total Phosphorus ranged between 0.02 and $23.60 \mathrm{mg} / \mathrm{l}$. This exceeded the recommended guideline value of $0.03 \mathrm{mg} / \mathrm{l}$ for freshwater sources. (Government of Canada, 2008). Station variations of Total phosphorus were found to be statistically significant $(\mathrm{p}<0.05)$. Although phosphorus is an essential nutrient for plant growth and for biological metabolism, Tjandraatmadja et al. (2010) argues that, excessive discharge into aquatic environments can result in excessive algae growth, eutrophication and the depletion of oxygen in water bodies. Mean concentration of Total Phosphorus was found to be high (15.78 mg/l) in Aboabo. This probably could be attributed to the poor sanitary conditions and the discharge of wastewater into the Aboabo River.

The concentrations of Nitrate ranged from $0.23 \mathrm{mg} / \mathrm{l}$ to $10.20 \mathrm{mg} / \mathrm{l}$. All the sampling stations had concentrations far below the $50 \mathrm{mg} / \mathrm{l}$ guideline value recommended by WHO (WHO, 2011). Therefore the assertions by Boatman et al. (1999) and UNEP (2008) concerning excessive Nitrate concentrations resulting in human health problems such as methaemoglobinaemia (blue baby syndrome), stomach cancer and negative reproductive outcomes does not call for immediate concerns.

Total dissolved solids are also an important parameter when looking at water quality. Results obtained indicate a range of 96.5 to $700 \mathrm{mg} / \mathrm{l}$. These values were within the acceptable limits of $1000 \mathrm{mg} / \mathrm{l}$ recommended by WHO. However, WHO (2011) reports that TDS levels less than about $600 \mathrm{mg} / \mathrm{l}$ is generally considered to be good whereas levels above $1000 \mathrm{mg} / \mathrm{l}$ raises palatability concerns.

Table 3. Summary findings of water quality analysis

\begin{tabular}{lccc}
\hline \multirow{2}{*}{ Parameter } & \multicolumn{3}{c}{ Data Summary } \\
\cline { 2 - 4 } & Minimum Value & Average Value & Maximum Value \\
\hline Temperature $\left({ }^{\circ} \mathrm{C}\right)$ & 25.80 & 31.40 & 36.20 \\
Nitrate $(\mathrm{mg} / \mathrm{l})$ & 0.23 & 3.37 & 10.20 \\
TDS $(\mathrm{mg} / \mathrm{l})$ & 96.50 & 452.33 & 700.00 \\
Total Phosphorus (mg/l) & 0.02 & 8.99 & 23.60 \\
Turbidity (NTU) & 1.29 & 68.56 & 377.00 \\
$\mathrm{pH}$ & 6.50 & 7.18 & 7.78 \\
\hline
\end{tabular}




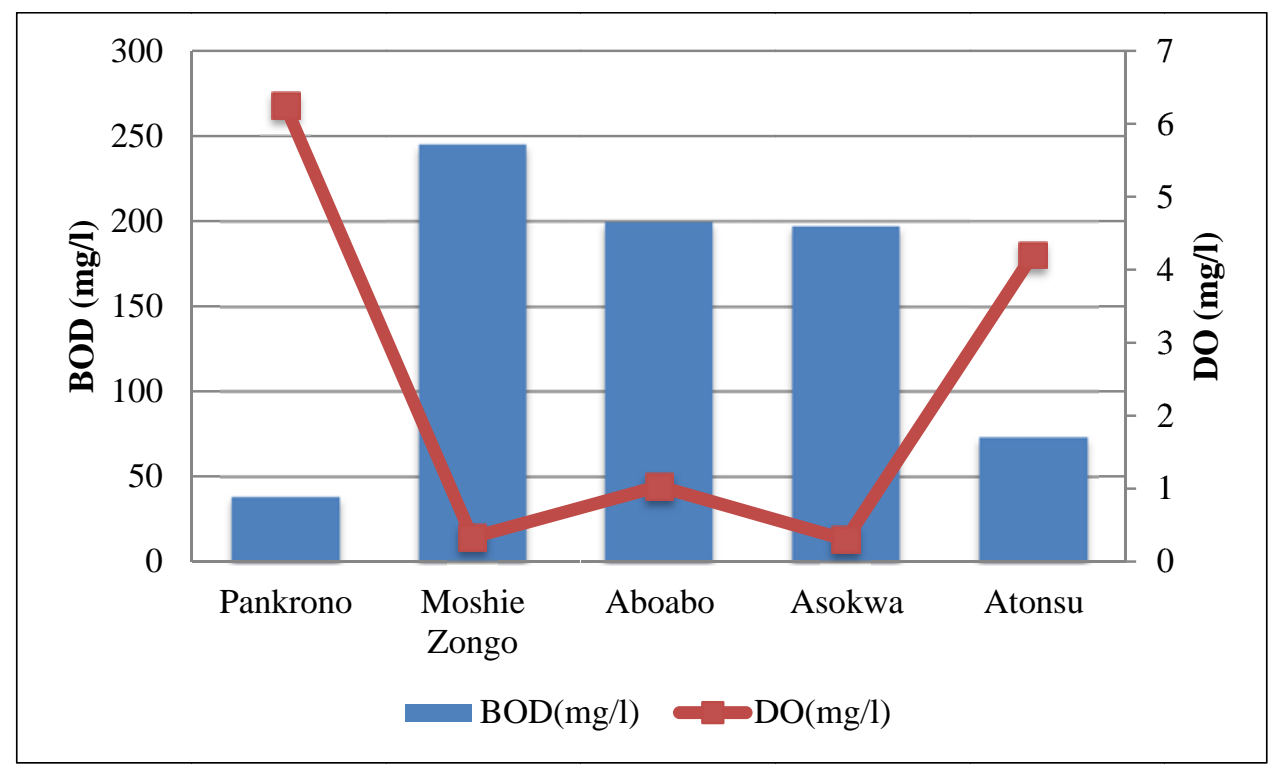

Figure 3. A comparison of BOD and DO concentrations

Mean concentrations of BOD ranged from $38.25-245.00 \mathrm{mg} / \mathrm{l}$ whiles that of DO ranged between 0.3 and 6.25 $\mathrm{mg} / \mathrm{l}$. A comparison of DO with BOD (Figure 3) suggests that as BOD increases, there is a drop in DO concentration. This confirms the assertion made by UNEP (2008) that systems with high BOD tend to have low dissolved oxygen concentrations. Low DO levels recorded are recipe for aquatic fatality and the ecosystem as a whole.

\section{Conclusions}

Discussions so far have brought to the fore the water quality issues that the Aboabo River is faced with. Pertinent in this regard is the model's prediction of the poor nature of the Aboabo River. The overall water quality index of 17.05 gives a clear indication of the deteriorating nature of the River. The implications of such levels of pollution are grave on aquatic life and also on raw water abstraction for water supply. In order to resuscitate the River, it is recommended that appropriate sanitary facilities be made available within the Aboabo catchment to avert the problem of direct discharge of waste into the river. The buffer zone policy regarding water resources established by the WRC should be enforced.

\section{Acknowledgements}

The authors of this work wish to acknowledge the support of Prof (Mrs) Esi Awuah for making funds available for the research.

\section{References}

Al-Janabi, Z. Z., Rahman-Al-Kubaisi, A., \& Al-Obaidy, A. (2012). Assessment of Water Quality of Tigris River By Using Water Quality Index (CCME WQI). Journal of Al-Nahrain University, 15(1), 119-126.

Boatman, N., Stoate, C., Gooch, R., Carvalho, C. R., Borralho, R., de Snoo, G., \& Eden, P. (1999). The environmental impact of arable crop production in the European Union: practical options for improvement. Prepared by Allerton Research and Educational Trust; Eurinco Ltd; ERENA; and Centre of Environmental Science, Lieden University. Environmental Commission Directorate-General, Environment, Nuclear Safety and Civil Protection: United Kingdom, Belgium, Portugal, the Netherlands. Retrieved July 4th, 2013, from http://ec.europa.eu/environment/agriculture/pdf/arable.pdf

Brungs, W. S., \& Jones, B. R. (1977). Temperature Criteria for Freshwater Fish: Protocols and Procedures. EPA-600/3-77-061. Environ. Research Lab, Ecological Resources Service, U.S. Environmental Protection Agency, Office of Research and Development, Duluth, MN.

CCME, Canadian Council of Ministers of the Environment. (2001). Canadian Water Quality Guidelines for the Protection of Aquatic Life: Canadian Water Quality Index 1.0 Technical Report. In Canadian Environmental Quality Guidelines, Winnipeg, Manitoba, Retrieved June 13th, 2013, from http://www.ccme.ca/assets/pdf/wqi_usermanualfctsht_e.pdf 
Chimnoy, C., \& Raziuddin, M. (2002). Determination of water quality indices (WQI) of a degraded river in Asanol industrial area. West Bengal. Nat. Env. and Poll. Tech., 1(2), 181-189.

Danquah, L., Abass, K., \& Nikoi, A. A. (2011). Antropogenic pollution of inland waters: the case of the Aboabo River in Kumasi, Ghana. Journal of Sustainable Development, 4(6). http://dx.doi.org/10.5539/jsd.v4n6p103

Devi Prasad, A. G., \& Kothathi, S. (2012). Application of CCME Water Quality Index to the Lakes of Mandya, Karnataka State, India. Online International Interdisciplinary Research Journal, 2(1).

Government of Canada. (2008). Technical guidance document for Water Quality Index practitioners reporting under the Canadian Environmental Sustainability Indicators (CESI) initiative.

Khan, A. A., Paterson, R., \& Khan, H. (2004). Modification and Application of the Canadian Council of Ministers of the Environment Water Quality Index (CCME WQI) for the Communication of Drinking Water Quality Data in Newfoundland and Labrador. Water Qual. Res. J. Canada, 39(3), 285-293.

Suraj, M. (2004). Urbanization and Water Resources Vulnerability in the Kumasi Metropolitan Area, Ghana. Unpublished MSc. Thesis submitted to the Department of Water and Environmental Studies at Linkoping University, Sweden.

Tjandraatmadja, G., Pollard, C., Sheedy, C., \& Gozukara, Y. (2010). Sources of Contaminants in Domestic Wastewater: Nutrients and Additional Elements from Household Products. CSIRO: Water for a Healthy Country National Research Flagship, Australia.

UNEP. (1997). Water pollution control- A guide to the use of water quality management principles. St Edmundsbury Press, Bury St Edmunds, Suffolk, Great Britain chapter 2.

USEPA. (2001). Parameters of water quality; Interpretation and standards.

UNEP. (2006). Water Quality for Eco-system and Human Health. UN GEMS /Water Programme Office c/o National Water Research Institute 867 Lake-shore Road Burlington, Ontario, L7R 4A6 CANADA Retrieved July 21st, 2013, from http://www.gemswater.org/

UNEP. (2007). Global Drinking Water Quality Index Development and Senstivity analysis report.

UNEP. (2008). Water quality for ecosystem and human health (2nd ed.). Retrieved July 28th, 2013, from http://www.gemswater.org

USEPA. (1997). Volunteer Stream Monitoring: A Methods Manual. EPA 841-B-97-003. Retrieved May 6th, 2013, from http://www.epa.gov/owow/monitoring/volunteer/stream/

WHO. (1993). Guidelines for Drinking Water Quality. World Health Organization, Geneva, Switzerland.

WHO. (2011). Guidelines for drinking-water quality (4th ed.).

\section{Copyrights}

Copyright for this article is retained by the author(s), with first publication rights granted to the journal.

This is an open-access article distributed under the terms and conditions of the Creative Commons Attribution license (http://creativecommons.org/licenses/by/3.0/). 